\title{
Release of Bet v 1 from birch pollen from 5 European countries. Results from the HIALINE study
}

\author{
Jeroen T.M. Buters ${ }^{\mathrm{a}, *}$, Michel Thibaudon ${ }^{\mathrm{b}}$, Matt Smith ${ }^{\mathrm{c}, \mathrm{d}, 1}$, Roy Kennedy ${ }^{\mathrm{c}}$, Auli Rantio-Lehtimäki ${ }^{\mathrm{e}}$ \\ Ingrid Weichenmeier ${ }^{\mathrm{a}}$, Gudrun Pusch ${ }^{\mathrm{a}}$, Hakan Sarioglu ${ }^{\mathrm{m}}$, Marius Ueffing ${ }^{\mathrm{m}}$, Heidrun Behrendt ${ }^{\mathrm{a}}$, \\ Marje Prank $^{\mathrm{n}}$, Mikhail Sofiev ${ }^{\mathrm{n}}$, Lorenzo Cecchi ${ }^{\mathrm{O}}$ The HIALINE working group \\ ${ }^{a}$ ZAUM - Center of Allergy and Environment, Helmholtz Zentrum München/Technische Universität München, Munich, Germany \\ ${ }^{\mathrm{b}}$ RNSA (Réseau National de Surveillance Aérobiologique), Brussieu, France \\ ${ }^{\mathrm{c}}$ National Pollen and Aerobiology Research Unit, University of Worcester, Worcester, UK \\ ${ }^{\mathrm{d}}$ Medical University of Vienna, Department of Oto-Rhino-Laryngology, Research Unit Aerobiology and Pollen information, Vienna, Austria \\ e University of Turku, CERUT, Aerobiology Unit, Turku, Finland \\ ${ }^{\mathrm{f}}$ Laboratory of Allergology, Department of Clinical Medicine, Nephrology and Health Sciences, University of Parma, Italy \\ ${ }^{g}$ Allergopharma Joachim Ganzer KG, Reinbek, Germany \\ ${ }^{\mathrm{h}}$ Department of Botany, Ecology and Plant Physiology, University of Córdoba, Córdoba, Spain \\ i ICAAM - Institute of Mediterranean Crop and Environmental Sciences, University of Evora, Evora, Portugal \\ ${ }^{\mathrm{j}}$ Aerobiology Laboratory, Biology Department, Science and Arts Faculty, Uludag University, Gorukle-Bursa, Turkey \\ ${ }^{\mathrm{k}}$ Laboratory of Aeropalynology, Faculty of Biology, Adam Mickiewicz University, Poznań, Poland \\ ${ }^{1}$ Department of Environmental research, Siauliai University, Siauliai, Lithuania \\ ${ }^{\mathrm{m}}$ Department of Protein Science, Helmholtz Zentrum München, Neuherberg, Germany \\ ${ }^{\mathrm{n}}$ Finnish Meteorological Institute, Helsinki, Finland \\ ${ }^{\circ}$ Interdepartmental Centre of Bioclimatology, University of Florence, Florence, Italy
} Roberto Albertini ${ }^{\mathrm{f}}$, Gerald Reese ${ }^{\mathrm{g}}$, Bernhard Weber ${ }^{\mathrm{g}}$, Carmen Galan ${ }^{\mathrm{h}}$, Rui Brandao ${ }^{\mathrm{i}}$, Celia M. Antunes ${ }^{\mathrm{i}}$, Siegfried Jäger ${ }^{\mathrm{d}}$, Uwe Berger ${ }^{\mathrm{d}}$, Sevcan Celenk ${ }^{\mathrm{j}}$, Łukasz Grewling $^{\mathrm{k}}$, Bogdan Jackowiak ${ }^{\mathrm{k}}$, Ingrida Sauliene ${ }^{\mathrm{l}}$,

\section{A R T I C L E I N F O}

\section{Article history:}

Received 17 November 2011

Received in revised form

20 January 2012

Accepted 23 January 2012

\section{Keywords:}

Birch

Pollen

Bet v 1

Exposure

Isoforms

ELISA

HIALINE

Human

Basophils

Europe

\begin{abstract}
A B S T R A C T
Exposure to allergens is pivotal in determining sensitization and allergic symptoms in individuals. Pollen grain counts in ambient air have traditionally been assessed to estimate airborne allergen exposure. However, the exact allergen content of ambient air is unknown. We therefore monitored atmospheric concentrations of birch pollen grains and the matched major birch pollen allergen Bet $v 1$ simultaneously across Europe within the EU-funded project HIALINE (Health Impacts of Airborne Allergen Information Network).

Pollen count was assessed with Hirst type pollen traps at $10 \mathrm{l} \mathrm{min}^{-1}$ at sites in France, United Kingdom, Germany, Italy and Finland. Allergen concentrations in ambient air were sampled at $8001 \mathrm{~min}^{-1}$ with a Chemvol ${ }^{\circledR}$ high-volume cascade impactor equipped with stages $\mathrm{PM}>10 \mu \mathrm{m}, 10 \mu \mathrm{m}>\mathrm{PM}>2.5 \mu \mathrm{m}$, and in Germany also $2.5 \mu \mathrm{m}>\mathrm{PM}>0.12 \mu \mathrm{m}$. The major birch pollen allergen Bet $\mathrm{v} 1$ was determined with an allergen specific ELISA. Bet $\mathrm{v} 1$ isoform patterns were analyzed by 2D-SDS-PAGE blots and mass spectrometric identification. Basophil activation was tested in an FceR1-humanized rat basophil cell line passively sensitized with serum of a birch pollen symptomatic patient.

Compared to 10 previous years, 2009 was a representative birch pollen season for all stations. About $90 \%$ of the allergen was found in the PM $>10 \mu \mathrm{m}$ fraction at all stations. Bet v 1 isoforms pattern did not vary substantially neither during ripening of pollen nor between different geographical locations. The average European allergen release from birch pollen was $3.2 \mathrm{pg}$ Bet v 1/pollen and did not vary much between the European countries. However, in all countries a $>10$-fold difference in daily allergen release per pollen was measured which could be explained by long-range transport of pollen with a deviating
\end{abstract}

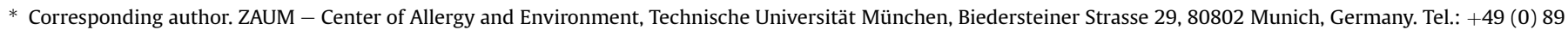
4140 3487; fax: +49 (0) 8941403453.

E-mail address: buters@lrz.tum.de (J.T.M. Buters).

URL: http://www.zaum-online.de

1 Medical University of Vienna, Department of Oto-Rhino-Laryngology, Research Unit Aerobiology and Pollen information, Vienna, Austria
} 
allergen release. Basophil activation by ambient air extracts correlated better with airborne allergen than with pollen concentration.

Although Bet v 1 is a mixture of different isoforms, its fingerprint is constant across Europe. Bet v 1 was also exclusively linked to pollen. Pollen from different days varied $>10$-fold in allergen release. Thus exposure to allergen is inaccurately monitored by only monitoring birch pollen grains. Indeed, a humanized basophil activation test correlated much better with allergen concentrations in ambient air than with pollen count. Monitoring the allergens themselves together with pollen in ambient air might be an improvement in allergen exposure assessment.

(c) 2012 Elsevier Ltd. All rights reserved.

\section{Introduction}

Allergies are the most prevalent chronic diseases in Europe with an $>20 \%$ prevalence (Bauchau and Durham, 2004; Sunyer et al., 2004; Bousquet et al., 2007). Allergic diseases to airborne allergens have been steadily increasing over the past decades (Eder et al., 2006). This increase in prevalence is also due to replacement of older less sensitized individuals in the population by younger individuals with a higher degree of sensitization (Jarvis et al., 2005; Rönmark et al., 2009; Laatikainen et al., 2011). For developed countries a leveling-off of allergic disease prevalence was reported (Asher et al., 2006; Grize et al., 2006), but for some highly developed countries like Finland an end of this epidemic is not in sight (Laatikainen et al., 2011).

Allergen exposure determines sensitization (Olmedo et al., 2011) and allergy symptoms correlate with exposure (Corrigan et al., 2005; Brito et al., 2011). Exposure to outdoor airborne allergens is monitored by determining the concentration of pollen in ambient air with EAN (European Aeroallergen Network) database, a network of over 350 pollen traps spread over Europe (www.ean-net.org, accessed January 2012). However, humans react to the allergen and the concentration of airborne pollen (the pollen count) is a proxy of exposure. Indeed, several investigations imply that the pollen count might not be representative for allergen exposure, also because allergen was found in non-pollen bearing fractions of ambient air (Schäppi et al., 1997b; De Linares et al., 2010; Fernandez-Gonzalez et al., 2011).

Pollen grains release more immunologically active compounds than only allergen, like PALMS, adenosine and NADPH oxidase (Dharajiya et al., 2007; Gilles et al., 2009, 2011). These compounds can act as adjuvants, however the allergen from pollen is the dominant factor for evoking symptoms (Brito et al., 2011).

Almost all patients allergic to birch pollen are allergic to Bet $\mathrm{v} 1$, sometimes accompanied by a sensitization to Bet $\mathrm{v} 2$ or Bet $\mathrm{v} 4$ (Moverare et al., 2005). The Bet v 1 content of birch pollen is not constant (Buters et al., 2010), and geographical variation was described (Buters et al., 2008). Climate change with increasing concentrations of $\mathrm{CO}_{2}$ results in higher pollen production as $\mathrm{CO}_{2}$ is both an airborne fertilizer and a greenhouse gas. Changes in allergen release per pollen would be in addition to the changed load of airborne pollen (Estrella et al., 2006; Rogers et al., 2006; Shea et al., 2008; Ziska and Beggs, 2012). We therefore determined the variation in the release of the major birch pollen allergen Bet $v 1$ with an immunochemical ELISA method in the project HIALINE (Health Impacts of Airborne Allergen Information Network) and confirmed this independently in selected cases with a bio-assay using FceR1-humanized rat basophils. We evaluated whether the used methods, Chemvol ${ }^{\circledR}$ and ELISA, were suited for an allergenrelease measuring network. We also investigated whether meteorological factors could govern allergen release from pollen, in an effort to predict the effect of climate change on the allergenicity of pollen.

\section{Materials and methods}

\subsection{Pollen count}

Airborne concentrations of pollen were sampled with volumetric spore traps of the Hirst design (Hirst, 1952) and examined by light microscopy as described before (Smith et al., 2009). Pollen counting methods vary historically between countries and three different methods were included in this study. Three stations used a technique where slides were examined along three (France) or four (Germany and Italy) longitudinal transects (Sikoparija et al., 2011). In the UK pollen grains were counted along twelve latitudinal transects (Smith et al., 2009). The analysis method used in Finland is random sampling of microscopic fields which has been shown to give parallel results to the counts carried out with the two other methods (longitudinal and latitudinal transects) (Mäkinen, 1981). Difference between methods was eliminated by correction for surface counted (Comtois et al., 1999). Pollen counts for the 10years average were obtained from the EAN (European Aeroallergen Network, https://ean.polleninfo.eu, accessed January 2012). The pollen season was calculated as described in the legend of Table 1. The pollen index, the total exposure to pollen from one season at

Table 1

Characterization of the different stations in 2009 (unless stated otherwise).

\begin{tabular}{|c|c|c|c|c|c|}
\hline & UK & France & Germany & Finland & Italy \\
\hline \multicolumn{6}{|l|}{ Pollen-flight } \\
\hline $\begin{array}{l}\text { Maximum birch pollen } \\
\text { count (grains } / \mathrm{m}^{-3} \text { ) }\end{array}$ & 278 & 622 & 495 & $253 / 250$ & 31 \\
\hline Day of highest peak & 15.04 & 14.04 & 11.04 & $27.04 / 16.05$ & 8.4 \\
\hline $\begin{array}{l}\text { Cumulative annual sum } \\
\left(\Sigma \text { grains } \mathrm{m}^{-3}\right)\end{array}$ & 2586 & 1705 & 3144 & 2923 & 235 \\
\hline $\begin{array}{l}\text { Average sum (1999-2009) } \\
\left(\Sigma \text { grains } \mathrm{m}^{-3}\right)\end{array}$ & 3103 & 1724 & 6848 & 10,160 & 773 \\
\hline Season length days ${ }^{a}$ & 24 & 28 & 19 & 30 & 48 \\
\hline \multicolumn{6}{|l|}{ Bet v 1} \\
\hline $\begin{array}{l}\text { Maximum Bet v } 1 \\
\left(\text { pg Bet v } 1 \mathrm{~m}^{-3}\right)\end{array}$ & 755 & 986 & 2299 & 978 & 82 \\
\hline $\begin{array}{l}\text { Cumulative Bet v } 1 \\
\left(\Sigma \text { pg Bet } \mathrm{v} 1 \mathrm{~m}^{-3}\right)\end{array}$ & 5969 & 7046 & 13,030 & 7634 & 681 \\
\hline $\begin{array}{l}\text { Bet v } 1 \text { per pollen } \\
(\text { pg Bet v } 1 / \text { pollen })^{\mathrm{b}}\end{array}$ & 2.260 & 3.057 & 3.914 & 2.617 & 2.569 \\
\hline \multicolumn{6}{|l|}{ Temperature $\left({ }^{\circ} \mathrm{C}\right)^{\mathrm{c}}$} \\
\hline Average & 9.0 & 11.1 & 7.9 & 4.2 & 13.7 \\
\hline Average daily min & 5.8 & 5.8 & 3.5 & -0.03 & 8.9 \\
\hline Average daily max & 13.9 & 16.6 & 12.8 & 8.9 & 18.6 \\
\hline Days above $2{ }^{\circ} \mathrm{C}^{\mathrm{d}}$ & 28 & 28 & 27 & 24 & 28 \\
\hline Days below $0{ }^{\circ} \mathrm{C}$ & 0 & 0 & 1 & 1 & 0 \\
\hline Humidity (\%) & 71.2 & 68.2 & 68.4 & 73.5 & 60.8 \\
\hline $\begin{array}{l}\text { Solar radiation at } \\
\quad \text { surface }\left(\mathrm{MJ} \mathrm{m}^{-2}\right) \text { c,e }\end{array}$ & 349.8 & 435.2 & 403.9 & $422.8 / 548.7$ & 414.7 \\
\hline Precipitation $\left(\mathrm{mm} \mathrm{day}^{-1}\right)^{\mathrm{c}}$ & 0.49 & 0.52 & 1.68 & 0.40 & 10.4 \\
\hline
\end{tabular}

a Season was defined as $1 \%$ till $95 \%$ of all birch pollen for that season, according the recommendations of the European Aeroallergen Network (EAN.polleninfo.eu).

b From linear regression.

c During the 4 weeks before birch pollen peak.

d Birch flower growing days, after van Vliet, Int. J. Climatol. 22, 1757-67, 2002.

e Extracted from ECMWF archive of operational forecasts. 
one station was expressed as the sum of daily average pollen concentrations according

$\int_{t=0}^{t \rightarrow \text { end }} C t \cdot d(t)$

and carries the unit $\Sigma$ pollen grains $\mathrm{m}^{-3}$.

Quality control of the pollen count was monitored by the UK partner. All partners filled in questionnaires requesting data on the siting and operation of the pollen trap and the preparation and counting of samples. In addition, calibration slides were sent to each station and everyone involved in counting pollen for the study examined the slides. The limits imposed on the quality control survey were: (1) pollen counts between 0 and 30 pollen grains $\mathrm{m}^{-3}$ had to be within \pm 10 pollen grains $\mathrm{m}^{-3}$; (2) pollen counts $>30$ pollen grains $\mathrm{m}^{-3}$ had to be within $\pm 30 \%$. The rule that pollen count between 0 and 30 pollen grains $\mathrm{m}^{-3}$ had to be within $+/-10$ pollen grains $\mathrm{m}^{-3}$ was introduced because very low pollen count can easily vary by more than 30\% (Sikoparija et al., 2011). This number $( \pm 30 \%)$ was also determined by Comtois et al. as the inherent variation of the method (Comtois et al., 1999).

The variability between Hirst type volumetric spore traps was determined with 3 samplers operating simultaneously over a 3-week period at $<5 \mathrm{~m}$ apart on a rooftop at $9 \mathrm{~m}$ above ground during the birch pollen season in Munich, Germany ( $n=63$, pollen between 0 and 4500 grains $\mathrm{m}^{-3}$ ).

\subsection{Airborne allergen sampling}

Air was sampled as previously described (Buters et al., 2010). In brief: $8001 \mathrm{~min}^{-1}$ ambient air was sampled on polyurethane foam with a high-volume Chemvol $^{\circledR}$ cascade impactor equipped with size class stages PM $>10 \mu \mathrm{m}$ and $10 \mu \mathrm{m}>\mathrm{PM}>2.5 \mu \mathrm{m}$ (Butraco Inc., Son, Netherlands) (Demokritou et al., 2002). In Munich, the stage $2.5 \mu \mathrm{m}>\mathrm{PM}>0.12 \mu \mathrm{m}$ was also sampled. Air flow was kept constant with a rotameter controlled high-volume pump (Digitel DHM-60, Ludesch, Austria). At each site, the Chemvol ${ }^{\circledR}$ sampler was located at equal height and within $5 \mathrm{~m}$ of a Hirst-type trap. For each station $\mathrm{Chemvol}^{\circledR}$ and Hirst type pollen samples were analyzed daily for identical time periods. Polyurethane foam impacting substrates were cut into 3 identical parts per day and stored at $\leq-20^{\circ} \mathrm{C}$ until extraction.

\subsection{Meteorological data}

Weather data (daily average temperature, daily average humidity, cumulative daily rainfall, average wind speed, and cumulative daily sunshine) were measured using sensors at the stations. Missing parameters were obtained from the closest nearby stations of the national weather services. In the UK this was the Pershore station, in France the station at the airport of Bron, in Germany station 3379, Munich City of the Deutsche Wetterdienst, in Finland it was Turku Artukainen (Airport) weather station. In Italy all was measured at the same location as the Chemvol sampler.

\subsection{Extraction and analysis of Bet $v 1$}

The Chemvol ${ }^{\circledR}$ polyurethane impacting substrates were extracted for $4 \mathrm{~h}$ in $0.1 \mathrm{M}$ ammonium bicarbonate pH8.1 in a head-overhead rotator. Extracts were aliquoted, frozen, lyophilized and stored at $\leq-20^{\circ} \mathrm{C}$. Aliquots were reconstituted in $0.1 \mathrm{M}$ phosphate buffered saline pH7.4, serial diluted and allergen was determined by using a 2-site binding assay based on monoclonal antibodies in an ELISA format. Monoclonal antibodies 4B10 and 2E10 specific for
Bet $\mathrm{v} 1$, natural purified Bet $\mathrm{v} 1$ standards and controls were provided by our partner Allergopharma KG, Reinbek, Germany (Chapman et al., 2008; Kahlert et al., 2008).

With each ELISA two control samples of different concentration were analyzed. The values of these controls had to be within $25 \%$ of a reference value for the ELISA to be accepted. Then only those values of serial dilution that yielded the same concentration were reported.

For each day at least two filter parts were independently analyzed. If two filter parts did not yield a value within $25 \%$ of each other, a third extraction was performed and analyzed. The final reported concentration of each day was the mean of all valid determinations, mostly the mean of at least 16 ELISA wells. The same Standard Operating Procedure (SOP) was used by all partners, which included written data inclusion rules.

\subsection{Bet $v$ 1-isoform analysis}

Pollen was sampled sequentially from several locations across Europe (not always the stations were the allergen measurements were done) as described previously by Buters et al. (Buters et al., 2010) and shipped at $-20{ }^{\circ} \mathrm{C}$ to our partner at Allergopharma. Pollen from the day of pollination of each Betula pendula tree were extracted (see above) and subjected to 2D-SDS-PAGE electrophoresis using a first dimension of isoelectric focusing between $\mathrm{pH} 4-7$ (IPG strips, GE Healthcare, Munich) and a second dimension of SDSPAGE (Excel SDS gel, 12-14\%, GE Healthcare, Munich) for size separation. Gels were stained with Coomassie Brilliant Blue and dried. Available recombinant Bet v 1.0401 (Bet v 1d) and Bet v 1.0601 (Bet v 1f) were a kind gift of Prof. F. Ferreira, University of Salzburg, Austria, recombinant Bet v 1.0101 was from Allergopharma. Spots were quantified using Proteomweaver software (Definiens, Munich, Germany) and expressed as relative \% of the sum of all intensities. Punched spots were identified by tryptic digestion and analysis by mass spectrometry as described by Sarioglu et al. (2008).

\subsection{Degranulation of humanized $R B L$}

The humanized rat basophil cell line RBL-2H3 clone h21 expressing the $\alpha, \beta$, and $\gamma$ chain of the human Fc\&R1 was a kind gift of Prof. S. Vieths, Paul Ehrlich Institute, Langen, Germany. Cells were grown under standard conditions (Vogel et al., 2005) and were passively sensitized with serum of a birch pollen symptomatic patient (skin prick test positive and RAST $>3$ ). Dilutions of daily Chemvol samples were added to the cells and degranulation was quantitated as $\beta$-hexosaminidase release, determined as nitrophenol release from pNAG (p-nitrophenol-D-2-acetamido-2deoxyglucopyranosid, Sigma-Aldrich Corp, St. Louis, MO) in relation to total $\beta$-hexosaminidase activity after lysis of the cells with 1\% Triton-X100 (Vogel et al., 2005). Only values within the linear dose-response range of the cells (5-45\% degranulation) were reported. Because extracts vary greatly in Bet v 1 content, degranulation was calculated as if $1 \mathrm{~m}^{3}$ air was given to the cells. This could result in hypothetical degranulations of up to $800 \%$.

\subsection{Modeling}

The System for Integrated modeLling of Atmospheric coMposition (SILAM, (Sofiev et al., in press)) was used to compute the footprints of the observations and also to evaluate the flowering season.

A footprint of a single observation is, by definition, a surface area that delineates the sources that are responsible for the observed atmospheric concentrations. Interpreted in probabilistic terms, the 
footprint shows the probability of a specific air parcel to reach the observational site. The areas, for which this probability is not zero, comprise the footprint of the particular observation. As a simplification, all sources located within the footprint area would influence this observation, and no sources located outside the footprint area would affect it. The specific contributions of these sources vary depending on the footprint value: the higher the value, the stronger the source impact. Computations of the footprint with standard dispersion models are prohibitively resource-consuming, while the adjoint modeling used in this study generates the solution with reasonable efforts (Sofiev et al., 2006b).

The flowering season prediction followed the thermal-type model as described before (Sofiev et al., 2006a; Siljamo et al., 2008a,b). The SILAM model was run with a time step of 15 min and evaluated the transport for $60 \mathrm{~h}$ backward in time, for each daily observation at each site. The configuration included 8 vertical layers up to $\sim 6 \mathrm{~km}$ above the ground. The horizontal grid cell size was $25 \mathrm{~km}$ and the domain of simulations covered almost the whole of Europe. Meteorological information was taken from the operational archives of the European Center of Medium Range Weather Forecast (ECMWF). This data had a spatial resolution of about $25 \mathrm{~km}$ and time step of $3 \mathrm{~h}$.

\subsection{Statistical analysis}

Differences were analyzed with a paired Student's $t$-test unless stated otherwise (Livingston, 2004). A $p$ value $<0.05$ was considered statistically significant. Outliers were defined as more than 3 standard deviations of the mean. The relationship between allergen and pollen count was presented graphically by scatter plot. The strength of the relation was expressed by the coefficient of correlation $\left(r^{2}\right)$ which was calculated by using linear regression (Lorenz, 1989). The same pre-given spreadsheet was used for all calculations.

\section{Results}

\subsection{Pollen count}

Although the pollen counting method differed between the stations, this was compensated by correcting for the counted surface area and reporting the number as pollen grains $\mathrm{m}^{-3}$. This is a common method also used by EAN. Indeed, when we counted the same slides for birch pollen both latitudinal or longitudinal $(n=15)$ in the same laboratory by the same operator this resulted in a $<7 \%$ difference, in agreement with the literature for other pollen species (Carinanos et al., 2000).

In our network out of a total of 28 calibration counts for Betula, three were outside the limits imposed on the Quality Control survey (11\%).

The variability of pollen counts at the same location between 3 Hirst type pollen traps was $23 \%$. Recounting pollen from the same slide $(n=8)$ by the same operator showed a $<4 \%$ variability in counting reproducibility, the same as reported before (Kapyla and Penttinen, 1981). Thus $19 \%$ of the variation in birch pollen count is due to differences between the samplers.

The annual sum of pollen (pollen index, see methods) in 2009 varied between $235 \mathrm{\Sigma}$ pollen grains $\mathrm{m}^{-3}$ in Italy to $3144 \mathrm{\Sigma}$ grains $\mathrm{m}^{-3}$ in Germany (see Table 1). The average annual birch pollen count in 2009 was 55\% of the 1999-2009 average birch pollen flights for these stations (range 30-90\%, see Table 1), and similar years did occur for each station (data not shown). Thus the birch pollen season in 2009 was representative for all stations. Other European stations (not in this manuscript) report higher 10year average counts for birch pollen (i.e. central Finland, Poland or
Ukraine), as the center of birch tree habitat is the eastern part of Europe just outside the European Union (www.polleninfo.org, accessed January 2012). Thus our results cover the extremes of the European Union habitat for birch trees.

\subsection{Airborne pollen allergen}

The detection limit of the ELISA was $0.7 \mathrm{ng}$ Bet $\mathrm{v} 1 \mathrm{ml}^{-1}$, which equals 2.1 pollen $\mathrm{m}^{-3}$. Running a high and a low control concomitant with each run monitored the performance of the Bet $\mathrm{v}$ 1ELISA. Data inclusion rules were installed. The variability of the ELISA ( $n=66$, all stations, see Table 2 ) of the low control ( $\left.1.9 \mathrm{ng} \mathrm{ml}^{-1}\right)$ was $17.4 \%$ and $12.8 \%$ for the high control $\left(7.4 \mathrm{ng} \mathrm{ml}^{-1}\right)$, in close agreement with the literature (Schäppi et al., 1996; Buters et al., 2010). The pollen count and allergen Bet v 1 concentrations are depicted in Fig. 1. Allergen was $89.6 \pm 1.5 \%$ found in the $\mathrm{PM}>10 \mu \mathrm{m}$ fraction, the remainder was in the $10 \mu \mathrm{m}>\mathrm{PM}>2.5 \mu \mathrm{m}$ fraction, and none in the smallest $2.5 \mu \mathrm{m}>$ PM $>0.12 \mu \mathrm{m}$ fraction, available only in Munich. No allergen was found when no pollen was detected (see Fig. 1). The European average Bet v 1 release per pollen was $3.2 \mathrm{pg}$ Bet v 1/ pollen $\left(r^{2}=0.714\right.$, see Fig. 2$)$. However, the difference in allergen release per pollen between days and locations was $>10$-fold, even if we deleted all pollen count $<10$ pollen $\mathrm{m}^{-3}$ to avoid high allergen release values due to less reliable (low) pollen count. When we removed (arbitrarily) the Bet $\mathrm{v} 1$ release values per pollen stemming from pollen count $<10$ pollen $\mathrm{m}^{-3}$, then the average allergen release per pollen of the $10 \%$ lowest values was $0.61 \mathrm{pg}$ Bet $\mathrm{v} 1$ / pollen, the average of the highest $10 \%$ released 8.76 pg Bet $v 1 /$ pollen. Within each station, the average allergen release of the highest $5 \%$ and the lowest $5 \%$ values also varied at least $>10$-fold (see Fig. 2). Between countries the average allergen release per pollen were considered similar as the observed differences are within the uncertainties in pollen count (method variation $<30 \%$ ) or ELISA determination (method variation $<17 \%$ ).

\subsection{Bet $v 1$ isoforms}

Bet $\mathrm{v} 1$ is increasingly expressed during ripening in the last week before pollination (Buters et al., 2010). The pattern of Bet $v 1$ isoforms during ripening was determined using one tree (see Fig. 3).

Table 2

Values of the quality control of the Bet $v 1$ ELISA for the different stations across Europe. With each ELISA duplicates of a high and low standard were performed and cumulated in this table.

\begin{tabular}{|c|c|c|c|c|c|}
\hline & & \multicolumn{4}{|l|}{ Bet v 1} \\
\hline & & \multicolumn{2}{|c|}{ Control high } & \multicolumn{2}{|c|}{ Control low } \\
\hline & & $\mathrm{ng} \mathrm{ml} \mathrm{m}^{-1}$ & $\%$ of mean & $\mathrm{ng} \mathrm{ml} \mathrm{m}^{-1}$ & $\%$ of mean \\
\hline \multirow[t]{3}{*}{ Finland } & Avg & 7.65 & 103.1 & 1.61 & 84.6 \\
\hline & s.d.\% & 12.8 & & 25.8 & \\
\hline & $n$ & 19 & & 19 & \\
\hline \multirow[t]{3}{*}{ Germany } & Avg & 8.71 & 117.4 & 2.18 & 114.7 \\
\hline & s.d.\% & 13.4 & & 13.7 & \\
\hline & $n$ & 54 & & 54 & \\
\hline \multirow[t]{3}{*}{ Italy } & Avg & 7.73 & 104.2 & 2.33 & 122.3 \\
\hline & s.d.\% & 8.7 & & 5.5 & \\
\hline & $n$ & 12 & & 12 & \\
\hline \multirow[t]{3}{*}{ UK } & Avg & 6.74 & 90.8 & 1.63 & 85.8 \\
\hline & s.d.\% & 9.9 & & 8.4 & \\
\hline & $n$ & 24 & & 24 & \\
\hline \multirow[t]{3}{*}{ France } & Avg & 6.26 & 84.4 & 1.76 & 92.6 \\
\hline & s.d.\% & 41.4 & & 24.1 & \\
\hline & $n$ & 11 & & 11 & \\
\hline Average & & 7.42 & 100.0 & 1.90 & 100.0 \\
\hline s.d. & & 1.0 & & 0.3 & \\
\hline s.d.\% & & 12.8 & & 17.4 & \\
\hline
\end{tabular}



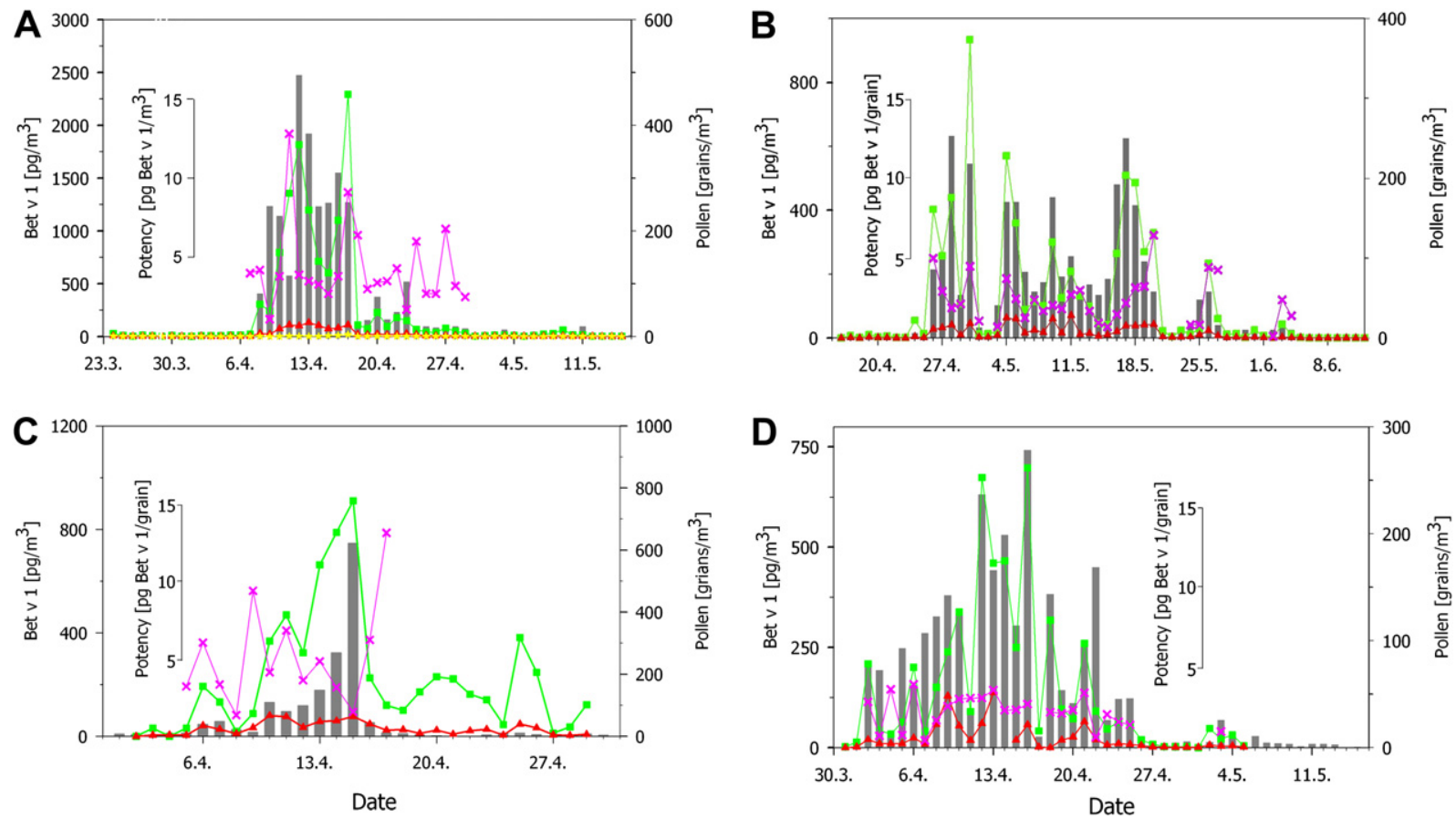

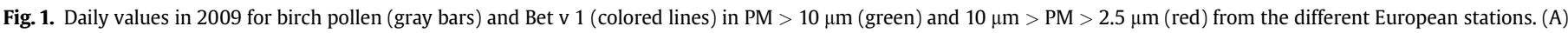

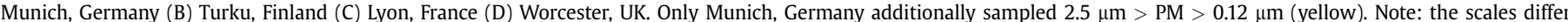

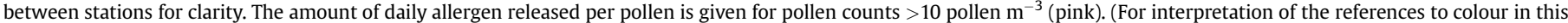
figure legend, the reader is referred to the web version of this article.)

Spots of April 18th were identified using mass spectrometry and, if available, by using pure recombinant isoforms.

The isoform pattern of Bet $\mathrm{v} 1$ did not differ markedly during ripening (see Fig. 3). Thus the same fingerprint of isoforms is expressed at rising concentrations during pollen ripening. An exception is spot 1 , which was analyzed as being a truncated isoform of Bet v 1.0101 (Bet v 1a), which increases upon ripening of the pollen. However, this was a minor Bet $\mathrm{v} 1$ isoform.

The ELISA antibody combination recognized all isoforms equally as pooled human serum. The ELISA antibodies did not recognize the isoform Bet v 1.0401 (Bet v 1d), which was also not recognized by pooled human serum from 10 donors (data not shown) (van Ree et al., 2008). Our ELISA thus represents human reactivity.

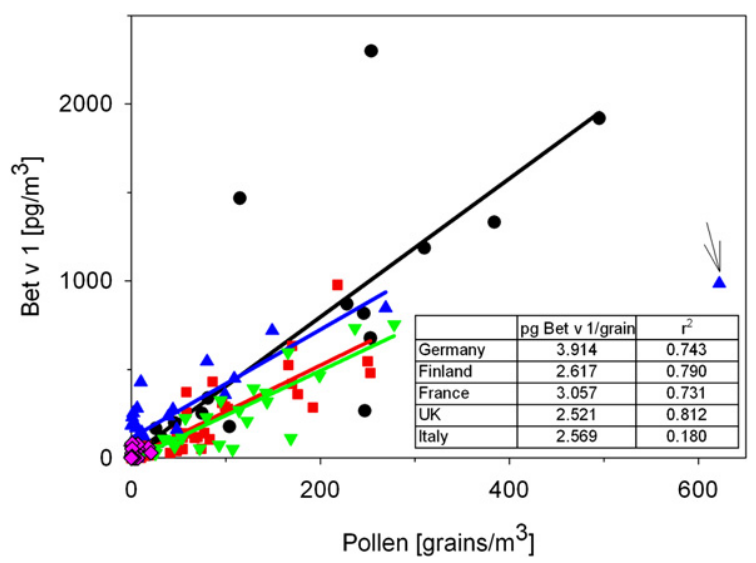

Fig. 2. Correlation between the total releasable allergen in the air and pollen count in the different countries in 2009. The slope of each linear regression curve represents the average Bet $\mathrm{v} 1$ release per pollen for that country. Each point represents duplicate determinations of one day in one country. - $\bullet$ - Germany; - - - Finland; - $\mathbf{A}$ - France; $\nabla$ - United Kingdom; - $>$ - Italy. The data point indicated with the arrow was treated as an outlier.
The isoform pattern of birch pollen from several different locations across Europe varied marginally, see Fig. 4. Because ripening of the pollen does not influence the isoform pattern, harvesting at not exactly the same time points before pollination would not explain differences. We conclude that the Bet $\mathrm{v} 1$ isoform pattern is the same during ripening and the same across Europe.

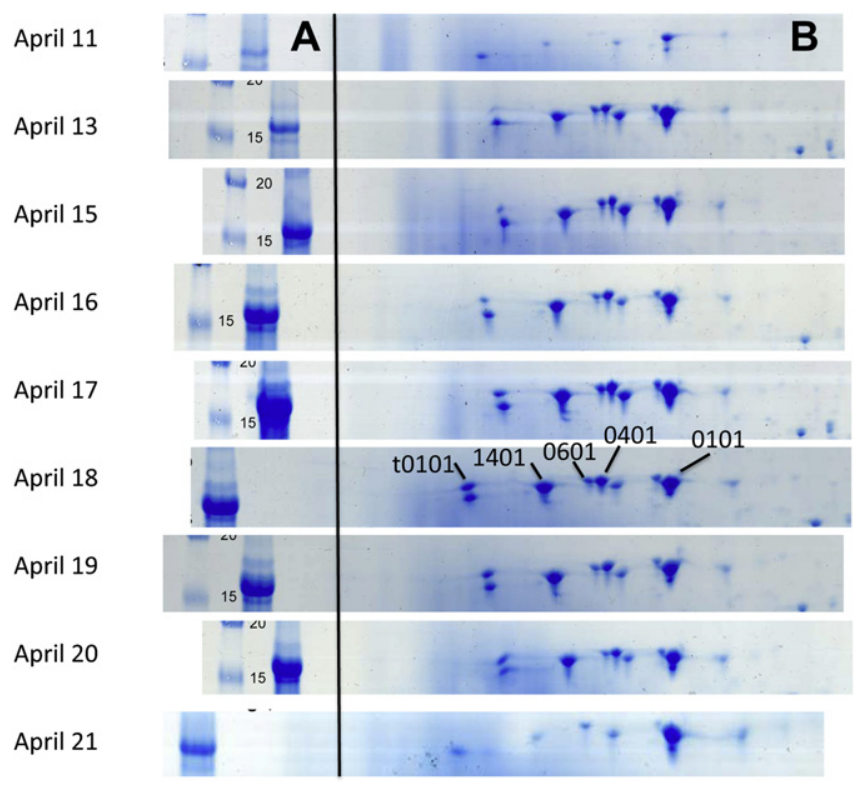

Fig. 3. One D (A) and 2D (B) SDS-PAGE of $0.1 \mathrm{M}$ ammonium bicarbonate extracts from pollen harvested sequentially in 2008 from one tree in Germany. April 19-20 were days of maximum pollination of that tree. Lane A is the image of the blot of the molecular weight marker $(15 \mathrm{kDa})$ and pollen extract after separating according to size. Identity of the spots was determined for April 18th. Spot 0101 represents Bet v 1.0101(Bet v 1a), the others are Bet v 1.0401(Bet v 1d), Bet v 1.0601 (Bet v 1f), Bet v 1.1401 (Bet v 1m) and truncated Bet v 1.0101(t0101, see methods). 


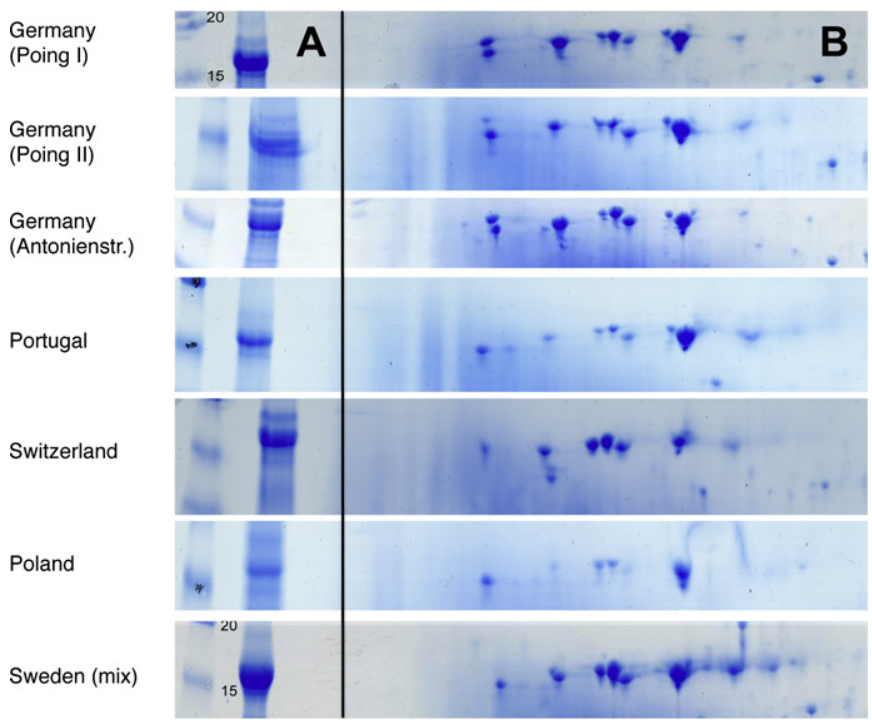

Fig. 4. Isoforms of Bet v 1 from trees across Europe in 2009. The same methodology as for Fig. 3 is used.

Our antibodies recognized all isoforms except the hypoallergenic isoform Bet v 1.0401, like humans (data not shown) (see Fig. 3) and the difference in Bet $v 1$ content between the stations is thus due to differences in amount of released Bet $v 1$, not due to release of different isoforms.

\subsection{Degranulation of basophils}

Rat basophils carrying the human Fc\&R1-receptor were passively sensitized with serum of a birch pollen sensitive individual and incubated with daily extracts of Chemvol samples from Munich, Germany. The reactivity of the cells is depicted in Fig. 5. Again, degranulation was only seen when pollen were counted. In addition, $\beta$-hexosaminidase release correlated well $\left(r^{2}=0.95\right.$, insert in Fig. 5A) with Bet $v 1$ concentration in ambient air, but less well with pollen count from Munich $\left(r^{2}=0.71\right.$, see insert in Fig. 5B). The level of detection, defined as $10 \%$ degranulation above baseline, was $0.2 \mathrm{ng} \mathrm{ml}^{-1}$ Bet v 1 .

\subsection{Modeling}

For this analysis, due to uncertainties in pollen counts and allergen determination, we omitted pollen counts below 15 pollen $\mathrm{m}^{-3}$ and allergen content below $10 \mathrm{pg} \mathrm{m}^{-3}$. Above this values the measurements are more robust. Analysis of the time series of the allergen release per pollen grain shows several features: (i) an established value for allergen release per pollen, which is steadily between 2 and $4 \mathrm{pg}_{\text {grain }}{ }^{-1}$ during the whole season for all stations, (ii) small fluctuations around this value, which are probably due to uncertainty of both Bet $\mathrm{v} 1$ and pollen observations, (iii) several episodes at some stations lasting for a few days, during which the allergen content differs from the average level by several-fold.

By joint analysis of the observation footprints and flowering patterns, the allergen content during the multi-day episodes can be correlated with geographical location of the pollen sources, as shown in Fig. 6. The allergen content observed in Turku is systematically low during the period 12-17 May, with the gradual decrease during 12-15 May down to less than $1 \mathrm{pg}^{\text {pollen }}{ }^{-1}$ and then increase again during 15-17 May. The footprint analysis showed that the transport direction of pollen was gradually changing from central Sweden to northern Finland and then
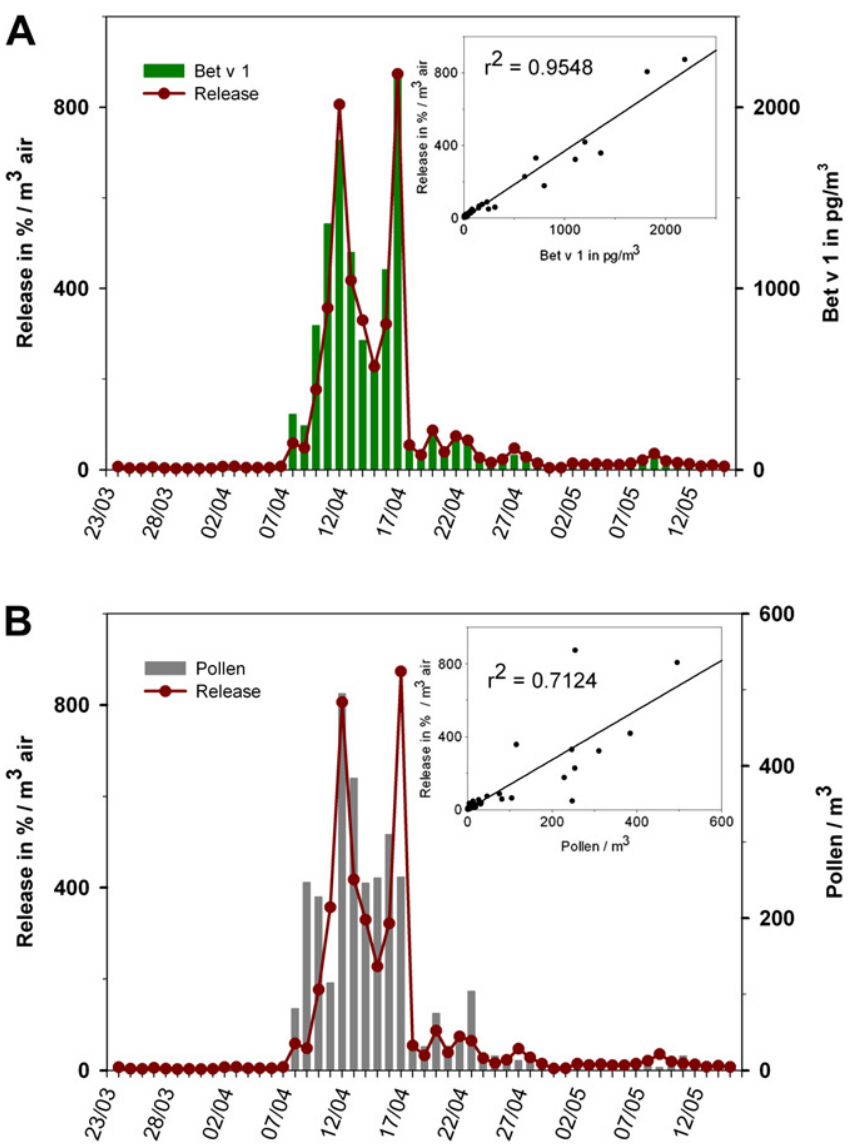

Fig. 5. $\beta$-hexosaminidase release (a proxy of histamine release) of Fc\&R1-humanized RBL cells after passive sensitization with serum of a birch pollen sensitized individual (see methods) and exposure to daily samples of TUM2009. Samples were diluted to fit the dynamic range of the cells. Degranulation per cubic meter air was then calculated and depicted and may exceed $100 \%$. (A) Bet v 1 concentrations and $\beta$ hex-(B) Pollen concentration and $\beta$-hexosaminidase release.

further to southern Finland. All these areas were flowering during these days. This suggests that the pollen originating from northern Finland showed an about three-times lower allergen release than that from the more southern regions. A similar pattern was seen again 24 and 25 May when the footprint was covering northern Sweden, which was flowering at that time (not shown). There was again a 3 times lower allergen release in pollen from the north than during the days when pollen originated from more southern regions.

In Munich, the episode during April 16-18 was characterized with high allergen content, flanked before and afterwards by several days with an average allergen release per pollen. Before and after that period the footprint shows the source areas to the east and somewhat to the south of Munich and the allergen release was at the average level. However, during the episode, the pollen mainly originated from mountains of Switzerland, where birch was at full flowering. Those grains had 2-3 times more allergen release than regions to the east of Munich. The part of footprint covering the Alps was probably void because there was no flowering in the high mountains yet.

\section{Discussion}

Birch pollen and the major birch pollen allergen Bet $\mathrm{v} 1$ were sampled during the birch pollen season in France, United Kingdom, 

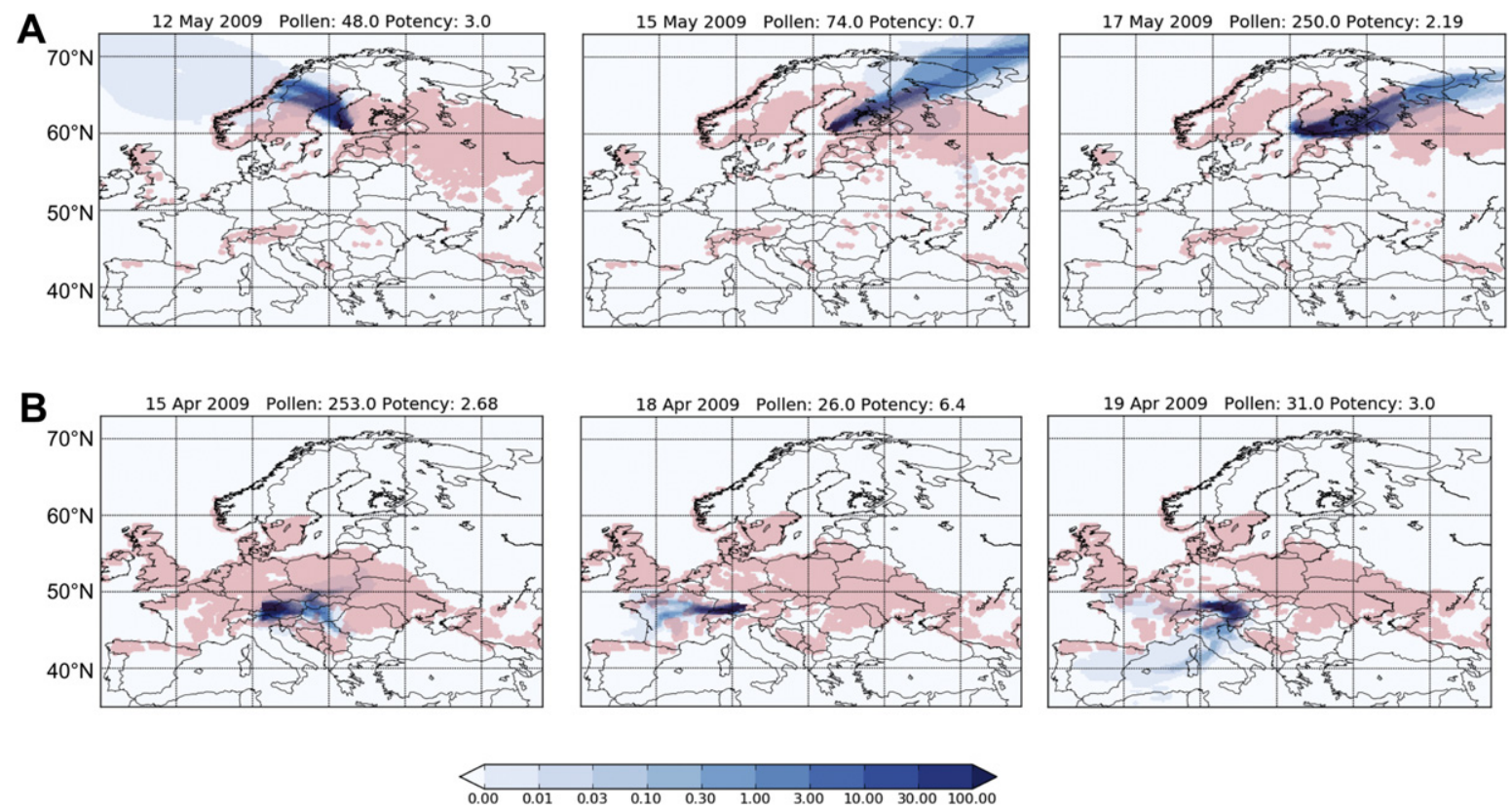

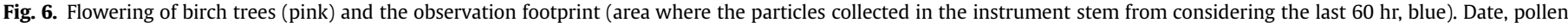

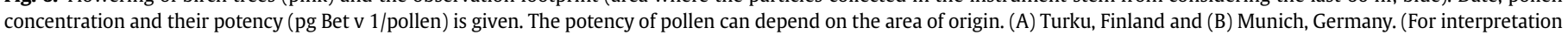
of the references to colour in this figure legend, the reader is referred to the web version of this article.)

Germany and Finland (and some data from Italy). The birch pollen season in 2009 was a representative year for all stations.

We did not find any large difference in Bet $\mathrm{v} 1$ isoform patterns during ripening of the pollen or across Europe, except for a minor isoform (truncated Bet v 1.0101, less than $5 \%$ of total Bet v 1 ). The isoform pattern recognized by ELISA was identical to the pattern recognized by a serum pool of birch allergic individuals. The average Bet $\mathrm{v} 1$ release per pollen from the different stations was within the error of the methods for pollen counting (30\%) and ELISA (17\%) and we consider the Bet v 1 release from pollen in 2009 similar across Europe. However, daily Bet v 1 release varied $>10-$ fold in all countries. This was independently confirmed with a bio-assay for Bet v 1 using human sIgE in humanized rat basophils. Indeed, $\beta$-hexosaminidase release in these cells as a proxy for histamine release correlated better with Bet v 1 than with pollen concentrations.

We conclude that birch pollen can vary $>10$-fold in allergen release and that this variation is similar across Europe.

\subsection{Pollen count}

Although pollen counts in Europe have been performed using standard methods for decades (Hirst, 1952), little is known about the reproducibility of Hirst type volumetric spore traps (Barral et al., 2009). In Munich, birch pollen count recorded by three volumetric pollen traps simultaneously varied by $19 \%$ for birch pollen. Comparing the different pollen counting methods (longitudinal, latitudinal and random) by sending calibration slides to all stations showed that the majority of birch pollen count (89\%) varied by less than $30 \%$, in agreement with previous publications (Comtois et al., 1999; Carinanos et al., 2000; Sikoparija et al., 2011).

Comtois et al. suggested that there will always be imprecision linked with the airborne pollen count unless aerobiologists count the whole slide, and even then variation between pollen traps will still be present. There is always a trade off between precision and the amount of time required to produce the daily pollen count (Comtois et al., 1999).
Based on these results and the literature we believe that a variation of $<30 \%$ in our data for pollen count is already accounted for by the pollen sampling and counting methodology and is not due to variations in nature.

The pollen season in 2009 was a representative year for all stations, as the average annual sum of birch pollen in 2009 was $55 \%$ (range $30-90 \%$ ) of the 10-year average for each station with no outliers (see Table 1). The stations also cover a larger geographic area within Europe.

\subsection{Allergen Bet $v 1$ in ambient air}

The $\mathrm{pH}$ of the extraction buffer is likely to influence the amount and isoform pattern of the allergens extracted. We used a slight alkaline extraction buffer, a condition observed in nasal fluid of allergic patients (Podoshin et al., 1991) and recommended by Cadot et al. for the appearance of relevant isoforms (Cadot et al., 1995). Indeed, extraction at pH8.1 was used by several, but not all authors (Rantio-Lehtimäki et al., 1994; Schäppi et al., 1997b; Petersen et al., 2001).

The average Bet $\mathrm{v} 1$ release across Europe was 3.2 pg Bet v 1/ pollen and is similar to the value of $4 \mathrm{pg}$ Bet $\mathrm{v} 1$ /pollen reported before (Schäppi et al., 1997b). Schenk et al. also published that the variation in allergen release between birch species was limited (Schenk et al., 2011) but report higher allergen content per pollen, which could be due to their extraction method. Another difference with other authors is that in the current study pollen were sampled from ambient air and not from trees or commercial suppliers.

The average Bet $\mathrm{v} 1$ release per pollen per country did not vary much $(-23.1 \%$ in the UK and $+21.8 \%$ in Germany, see Fig. 2$)$ and could be explained by variations in methodology as we determined that between pollen samplers a variation of $23 \%$ existed and our ELISA has a $<17 \%$ variation between laboratories in agreement with the literature where $30 \%$ variations for pollen monitoring is reported (Comtois et al., 1999; Sikoparija et al., 2011) and similar variations were found for ELISA allergen determinations (Schäppi et al., 1996; van Ree et al., 2008). 
However, when comparing the $10 \%$ lowest allergen release values per pollen with the $10 \%$ highest values, the daily allergen release difference across Europe and also within each country was $>10$-fold. Several other authors also report differences in allergen release per pollen for birch and olive pollen (Pehkonen and Rantio-Lehtimäki, 1994; Schäppi et al., 1997a; De Linares et al., 2007; Buters et al., 2010; Brito et al., 2011). This study shows that the variation in allergen release per pollen is substantial but equally distributed across the European birch tree habitat.

Across Europe, about 90\% of the allergen was recovered from the $>10 \mu \mathrm{m}$ fraction, none in the $2.5 \mu \mathrm{m}>\mathrm{PM}>0.12 \mu \mathrm{m}$ fraction (only in Munich), and no allergen was detected when no pollen was detected, neither with our ELISA nor with a more sensitive bio-assay. This shows that the only source of allergen is birch pollen, in agreement with previous results where allergens were monitored for several years on a row at one location (Buters et al., 2010). Birch allergen containing particles were reported in the fractions $\mathrm{PM}<10 \mu \mathrm{m}$ (birch pollen have a geometric diameter of 21-24 $\mu \mathrm{m}$ (Brown and Irving, 1973; Rantio-Lehtimäki et al., 1994; Schäppi et al., 1999)) indicating in combination with our results that if such particles exist, their appearance is rare and might need specific atmospheric conditions like thunderstorms (D'Amato et al., 2008), which did not occur during our experiments.

\subsection{The role of Bet $v 1$ isoforms}

We found that the Bet v 1 isoform fingerprint was more or less constant during ripening and across Europe with minor variations (see Figs. 3 and 4), in agreement with other authors (Friedl-Hajek et al., 1999; Erler et al., 2011; Schenk et al., 2011). The isoform truncated Bet v 1.0101 did increase in expression upon ripening of the pollen, however this minor truncated Bet $v 1.0101$ isoform represented $<5 \%$ of total Bet v 1 isoforms. The identity of the spots was confirmed with LC-MS after tryptic digest (Sarioglu et al., 2008), and if possible, by comparison with recombinant proteins. Also, our antibodies did not recognize the hypoallergenic isoform Bet v 1.0401 (Bet v 1 d), similar to a pool of human serum (data not shown) and as reported by others (Friedl-Hajek et al., 1999; Erler et al., 2011). Thus the difference we measured must be due to different total concentrations of allergenic Bet v 1 of which $50-70 \%$ is Bet v 1.0101(Bet v 1a) (Erler et al., 2011).

\subsection{Clinical relevance}

We used an independent method from ELISA to determine allergen content in ambient air by taking human serum from a birch pollen sensitive individual and passively sensitizing basophils (see Fig. 5). Although human mast cells would be the preferred cells, few human mast cell lines are available and none has been shown to be suitable for allergen determination (Kirshenbaum et al., 2003; Guhl et al., 2010). Besides mast cells, basophils are also responsible for the clinical symptoms of allergy in humans (Gibbs, 2007). The basophil cell line with human Bet v 1 specific IgE as detector of environmental Bet $\mathrm{v} 1$, resulted in an immune response as seen with allergic individuals (Vogel et al., 2005). Although more tedious, this method is more sensitive than the ELISA, able to detect 0.2 ng Bet v $1 \mathrm{ml}^{-1}$ (defined as degranulation $>10 \%$ ). With this more sensitive bio-assay also no allergen was detected when no pollen were measured. Also, $\beta$-hexosaminidase release (a substitute marker for histamine release which is the hallmark of allergic disease), correlated well with Bet v 1 ambient concentrations $\left(r^{2}=0.95\right)$, but lesser good with pollen count $\left(r^{2}=0.72\right.$, see Fig. 5$)$.

\subsection{Modeling}

We found several multi-day episodes where the differences in pollen potency could be explained by differences in origin of the pollen (see Figs. 1 and 6). We omitted pollen counts below 15 pollen $\mathrm{m}^{-3}$ and allergen measurements below $10 \mathrm{pg} \mathrm{m}^{-3}$ to guarantee more robust data. We also focused on multi-day episodes, as one-day jumps of the pollen content are more difficult to analyze. In general, there can be three possible explanations for single day jumps:

(i) similar to multi-day episodes, the peaks may correspond to specific transport conditions and/or origin of the grains. However, footprint analysis did not reveal such dependence.

(ii) low pollen count means higher uncertainty of the allergen release per pollen. However, it should manifest itself as both anomalous high and low values, which is not the case: almost all low-count cases were characterized by the high allergen release.

(iii) there can be allergen present in air apart from the one encapsulated in the pollen grains (D'Amato et al., 2008). Even when the number of grains is low, this extra allergen could lead to high release estimates. The instrumentation used in the current study does not detect such allergen, thus does not allow an explicit check of this possibility. Using suitable equipment, no such free allergen was detected (Buters et al., 2010).

Several multi-day episodes were detected (see Fig. 6). They corroborate our finding with ELISA and the bio-assay that pollen is not constant in their allergen release.

Noteworthy, the average value also suggests some north-tosouth gradient: for Munich and Worcester the allergen release is about $3 \mathrm{pg}$ pollen ${ }^{-1}$, whereas for Turku it is about $2 \mathrm{pg}$ pollen $^{-1}$ (statistically non significant).

\section{Conclusions}

In daily samples taken during the birch pollen season in 5 European countries we could only detect allergen when pollen was present. Also allergen was predominantly found in the PM $>10 \mu \mathrm{m}$ fraction, the fraction where the pollen land in the cascade impactor. Thus Bet v 1 in ambient air was confined to birch pollen. With our method the average European allergen release per pollen was $3.2 \mathrm{pg}$ Bet v 1/pollen. The average allergen release in 2009 did not vary substantially between countries. However, a $>10$-fold difference between daily allergen release per pollen was detected in all countries. Thus pollen exposure qualitatively represents allergen exposure but not quantitatively. The allergen concentration also correlated better with the bio-assay for immune response than pollen concentration. Modeling showed that multi-day episodes exist were pollen from specific origins consistently varied in allergen release. Thus we expect allergen monitoring to be a more accurate predictor of human allergic symptoms than pollen count.

\section{Acknowledgment}

This publication arises from the project HIALINE that has received funding from the European Union, in the framework of the Health Programme with additional support from Christine Kühne Center for Allergy Research and Education (CK-CARE). The expert assistance of Christine Huber, Christine Weil, Satu Saaranen, Manuela Ugolotti, Isabella Usberti, Simon John, Peter Baker, Angela Pomeroy, Jose Carlos Prieto Baena, Alain Dorier, Audrey Passaret, 
and Gilles Oliver is greatly appreciated. Regula Gehrig is warmly thanked for sampling pollen sequentially in Switzerland.

\section{References}

Asher, M.I., Montefort, S., Bjorksten, B., Lai, C.K., Strachan, D.P., Weiland, S.K., et al., 2006. Worldwide time trends in the prevalence of symptoms of asthma, allergic rhinoconjunctivitis, and eczema in childhood: ISAAC phases one and three repeat multicountry cross-sectional surveys. Lancet 368 (9537), 733-743.

Barral, S., Oliver, G., Bordenave, L., Duseuax, M., Bex-Capelle, V., Squinazzi, F., et al., 2009. Pollinic content of the air in Paris: study about the representativeness of Pasteur station from 2003-2007. Pollut. Atmos. 201, 79-89.

Bauchau, V., Durham, S.R., 2004. Prevalence and rate of diagnosis of allergic rhinitis in Europe. Eur. Respir. J. 24 (5), 758-764.

Bousquet, P.J., Chinn, S., Janson, C., Kogevinas, M., Burney, P., Jarvis, D., 2007. Geographical variation in the prevalence of positive skin tests to environmental aeroallergens in the European Community Respiratory Health Survey I. Allergy 62 (3), 301-309.

Brito, F.F., Gimeno, P.M., Carnes, J., Martin, R., Fernandez-Caldas, E., Lara, P., et al., 2011. Olea europaea pollen counts and aeroallergen levels predict clinical symptoms in patients allergic to olive pollen. Ann. Allergy Asthma Immunol. 106 (2), 146-152.

Brown, H.M., Irving, K.R., 1973. The size and weight of common allergenic pollens. An investigation of their number per microgram and size distribution. Acta Allergol. 28 (2), 132-137.

Buters, J.T.M., Kasche, A., Weichenmeier, I., Schober, W., Klaus, S., TraidlHoffmann, C, et al. 2008. Year-to-year variation in release of Bet v. 1 allergen from birch pollen: evidence for geographical differences between West and South Germany. Int. Arch. Allergy Immunol. 145 (2), 122-130.

Buters, J.T.M., Weichenmeier, I., Ochs, S., Pusch, G., Kreyling, W., Boere, A.J., et al., 2010. The allergen Bet v. 1 in fractions of ambient air deviates from birch pollen counts. Allergy 65 (7), 850-858.

Cadot, P., Lejoly, M., Van Hoeyveld, E.M., Stevens, E.A., 1995. Influence of the pH of the extraction medium on the composition of birch (Betula verrucosa) pollen extracts. Allergy 50 (5), 431-437.

Carinanos, P., Emberlin, J., Galan, C., Dominguez-Vilches, E., 2000. Comparison of two pollen counting methods of slides from a Hirst type volumetric trap. Aerobiologia 16 (3/4), 339-346.

Chapman, M.D., Ferreira, F., Villalba, M., Cromwell, O., Bryan, D., Becker, W.M., et al., 2008. The European Union CREATE project: a model for international standardization of allergy diagnostics and vaccines. J. Allergy Clin. Immunol. 122 (5), 882-889.

Comtois, P., Alcazar, P., Neron, D., 1999. Pollen counts statistics and its relevance to precision. Aerobiologia 15, 19-28.

Corrigan, C.J., Kettner, J., Doemer, C., Cromwell, O., Narkus, A., 2005. Efficacy and safety of preseasonal-specific immunotherapy with an aluminium-adsorbed six-grass pollen allergoid. Allergy 60 (6), 801-807.

D'Amato, G., Cecchi, L., Liccardi, G., 2008. Thunderstorm-related asthma: not only grass pollen and spores. J. Allergy Clin. Immunol. 121 (2), 537-538.

De Linares, C., Nieto-Lugilde, D., Alba, F., Diaz de la Guardia, C., Galan, C., Trigo, M.M., 2007. Detection of airborne allergen (Ole e 1) in relation to Olea europaea pollen in S Spain. Clin. Exp. Allergy 37 (1), 125-132.

De Linares, C., Diaz de la Guardia, C., Nieto Lugilde, D., Alba, F., 2010. Airborne study of grass allergen (Lol p 1) in different-sized particles. Int. Arch. Allergy Immunol. 152 (1), 49-57.

Demokritou, P., Kavouras, I.G., Ferguson, S.T., Koutrakis, P., 2002. Development of a high volume cascade impactor for toxicological and chemical characterization studies. Aerosol Sci. Technol. 36, 925-933.

Dharajiya, N.G., Bacsi, A., Boldogh, I., Sur, S., 2007. Pollen NAD(P)H oxidases and their contribution to allergic inflammation. Immunol. Allergy Clin. North Am. 27 (1), 45-63.

Eder, W., Ege, M.J., von Mutius, E., 2006. The asthma epidemic. N. Engl. J. Med. 355 (21), 2226-2235.

Erler, A., Hawranek, T., Krückemeier, L., Asam, C., Egger, M., Ferreira, F., et al., 2011. Proteomic profiling of birch (Betula verrucosa) pollen extracts from different origins. Proteomics 11 (8), 1486-1498.

Estrella, N., Menzel, A., Krämer, U., Behrendt, H., 2006. Integration of flowering dates in phenology and pollen counts in aerobiology: analysis of their spatial and temporal coherence in Germany (1992-1999). Int. J. Biometeorol. 51 (1), 49-59.

Fernandez-Gonzalez, E., Rodriguez Rajo, F., Gonzalez Parrado, Z., Valencia Barrera, R.M., Jato, V., Grau Moreno, S., 2011. Differences in atmospheric emissions of poaceae pollen and Lol p 1 allergen. Aerobiologia 27, 301-309.

Friedl-Hajek, R., Radauer, C., O’Riordain, G., Hoffmann-Sommergruber, K., Leberl, K., Scheiner, O., et al., 1999. New Bet v. 1 isoforms including a naturally occurring truncated form of the protein derived from Austrian birch pollen. Mol. Immunol. 36 (10), 639-645.

Gibbs, B.F., 2007. Basophils: are they only shadow dancers in allergy or more...? EAACI Web Bulletin. doi:10.1594/eaacinet2007/EO/8-131207.

Gilles, S., Mariani, V., Bryce, M., Mueller, M.J., Ring, J., Behrendt, H., et al., 2009. Pollen allergens do not come alone: pollen associated lipid mediators (PALMS) shift the human immune systems towards a T(H)2-dominated response. Allergy Asthma Clin. Immunol. 5 (1), 3-9.
Gilles, S., Fekete, A., Zhang, X., Beck, I., Blume, C., Ring, J., et al., 2011. Pollen metabolome analysis reveals adenosine as a major regulator of dendritic cellprimed $\mathrm{T}(\mathrm{H})$ cell responses. J. allergy Clin. Immunol. 127 (2), 454-461.

Grize, L., Gassner, M., Wüthrich, B., Bringolf-Isler, B., Takken-Sahli, K. Sennhauser, F.H., et al., 2006. Trends in prevalence of asthma, allergic rhinitis and atopic dermatitis in 5-7-year old Swiss children from 1992 to 2001. Allergy 61 (5), 556-562.

Guhl, S., Babina, M., Neou, A., Zuberbier, T., Artuc, M., 2010. Mast cell lines HMC-1 and LAD2 in comparison with mature human skin mast cells-drastically reduced levels of tryptase and chymase in mast cell lines. Exp. Dermatol. 19 (9) $845-847$

Hirst, J.M., 1952. An automatic volumetric spore trap. Ann. Appl. Biol. 39, 257-265.

Jarvis, D., Luczynska, C., Chinn, S., Potts, J., Sunyer, J., Janson, C., et al., 2005. Change in prevalence of IgE sensitization and mean total IgE with age and cohort. J. Allergy Clin. Immunol. 116 (3), 675-682.

Kahlert, H., Suck, R., Weber, B., Nandy, A., Wald, M., Keller, W., et al., 2008. Characterization of a hypoallergenic recombinant Bet v. 1 variant as a candidate for allergen-specific immunotherapy. Int. Arch. Allergy Immunol. 145 (3), 193-206.

Kapyla, M., Penttinen, A., 1981. An evaluation of the microscopical counting methods of the tape in hirst-burkard pollen and spore trap. Grana 20 (2), 131-141.

Kirshenbaum, A.S., Akin, C., Wu, Y., Rottem, M., Goff, J.P., Beaven, M.A., et al., 2003 Characterization of novel stem cell factor responsive human mast cell lines LAD 1 and 2 established from a patient with mast cell sarcoma/leukemia; activation following aggregation of FcepsilonRI or FcgammaRI. Leuk. Res. 27 (8), 677-682.

Laatikainen, T., von Hertzen, L., Koskinen, J.P., Mäkelä, M.J., Jousilahti, P., Kosunen, T.U., et al., 2011. Allergy gap between Finnish and Russian Karelia on increase. Allergy 66 (7), 886-892.

Livingston, E.H., 2004. Who was student and why do we care so much about his $t$ Test? J. Surg. Res. 118 (1), 58-65.

Lorenz, R.J., 1989. Biometrie. Grundbegriffe der Biometrie. Gustav Fischer Verlag Stuttgart.

Mäkinen, Y., 1981. Random sampling in the study of microscopic slides. Rep. Aerobiol. Lab. Univ. Turku 5, 27-43.

Moverare, R., Petäys, T., Vartiainen, E., Haahtela, T., 2005. IgE reactivity pattern to timothy and birch pollen allergens in Finnish and Russian Karelia. Int. Arch. Allergy Immunol. 136 (1), 33-38.

Olmedo, O., Goldstein, I.F., Acosta, L., Divjan, A., Rundle, A.G., Chew, G.L., et al., 2011 Neighborhood differences in exposure and sensitization to cockroach, mouse, dust mite, cat, and dog allergens in New York City. J. Allergy Clin. Immunol. 128 (2), 284-292.

Pehkonen, E., Rantio-Lehtimäki, A., 1994. Variations in airborne pollen antigenic particles caused by meteorologic factors. Allergy 49 (6), 472-477.

Petersen, A., Suck, R., Hagen, S., Cromwell, O., Fiebig, H., Becker, W.M., 2001. Group 13 grass allergens: structural variability between different grass species and analysis of proteolytic stability. J. Allergy Clin. Immunol. 107 (5), 856-862.

Podoshin, L., Gertner, R., Fradis, M., 1991. Treatment of perennial allergic rhinitis with ascorbic acid solution. Ear Nose Throat J. 70 (1), 54-55.

Rantio-Lehtimäki, A., Viander, M., Koivikko, A., 1994. Airborne birch pollen antigens in different particle sizes. Clin. Exp. Allergy 24 (1), 23-28.

Rogers, C.A., Wayne, P.M., Macklin, E.A., Muilenberg, M.L., Wagner, C.J., Epstein, P.R., et al., 2006. Interaction of the onset of spring and elevated atmospheric $\mathrm{CO}_{2}$ on ragweed (Ambrosia artemisiifolia L.) pollen production. Environ. Health Perspect. 114 (6), 865-869.

Rönmark, E., Bjerg, A., Perzanowski, M., Platts-Mills, T., Lundbäck, B., 2009. Major increase in allergic sensitization in schoolchildren from 1996 to 2006 in northern Sweden. J. Allergy Clin. Immunol. 124 (2), 357-363.

Sarioglu, H., Brandner, S., Haberger, M., Jacobsen, C., Lichtmannegger, J. Wormke, M., et al., 2008. Analysis of 2,3,7,8-tetrachlorodibenzo-p-dioxininduced proteome changes in $5 \mathrm{~L}$ rat hepatoma cells reveals novel targets of dioxin action including the mitochondrial apoptosis regulator VDAC2. Mol. Cell. Proteomics 7 (2), 394-410.

Schäppi, G.F., Monn, C., Wütrich, B., Wanner, H.-A., 1996. Anaylsis of allergens in ambient aerosols: comparison of areas subjected to different levels of air pollution. Aerobiologia 12, 185-190.

Schäppi, G.F., Suphioglu, C., Taylor, P.E., Knox, R.B., 1997a. Concentrations of the major birch tree allergen Bet v. 1 in pollen and respirable fine particles in the atmosphere. J. Allergy Clin. Immunol. 100 (5), 656-661.

Schäppi, G.F., Taylor, P.E., Staff, I.A., Suphioglu, C., Knox, R.B., 1997b. Source of Bet v. 1 loaded inhalable particles from birch revealed. Sex. Plant Reprod. 10 (6) 315-323.

Schäppi, G.F., Taylor, P.E., Staff, I.A., Rolland, J.M., Suphioglu, C., 1999. Immunologic significance of respirable atmospheric starch granules containing major birch allergen Bet v. 1. Allergy 54 (5), 478-483.

Schenk, M.F., Cordewener, J.H., America, A.H., Peters, J., Smulders, M.J., Gilissen, L.J., 2011. Proteomic analysis of the major birch allergen Bet v. 1 predicts allergenicity for 15 birch species. J. Proteomics 74 (8), 1290-1300.

Shea, K.M., Truckner, R.T., Weber, R.W., Peden, D.B., 2008. Climate change and allergic disease. J. Allergy Clin. Immunol. 122 (3), 443-453.

Sikoparija, B., Pejak-Sikoparija, T., Radisic, P., Smith, M., Galan, C.G., 2011. The effect of changes to the method of estimating the pollen count from aerobiological samples. J. Environ. Monit. 13 (2), 384-390.

Siljamo, P., Sofiev, M., Ranta, H., Linkosalo, T., Kubin, E., Ahas, R., et al., 2008a. Representativeness of point-wise phenological Betula data collected in different parts of Europe. Glob. Ecol. Biogeogr. 17, 489-502. 
Siljamo, P., Sofiev, M., Severova, E., Ranta, H., Kukkonen, J., Polevova, S., et al., 2008b. Sources, impact and exchange of early-spring birch pollen in the Moscow region and Finland. Aerobiologia 24, 211-230.

Smith, M., Emberlin, J., Stach, A., Rantio-Lehtimäki, A., Caulton, E., Thibaudon, M. et al., 2009. Influence of the North Atlantic oscillation on grass pollen counts in Europe. Aerobiologia 25 (4), 321-332.

Sofiev, M., Siljamo, P., Ranta, H., Rantio-Lehtimäki, A., 2006a. Towards numerica forecasting of long-range air transport of birch pollen: theoretical considerations and a feasibility study. Int. J. Biometeorol. 50 (6), 392-402.

Sofiev, M., Siljamo, P., Valkama, I., Ilvonen, M., Kukkonen, J., 2006b. A dispersion modelling system SILAM and its evaluation against ETEX data. Atmos. Environ. $40,674-685$

Sofiev, M., Siljamo, P., Ranta, H., Linkosalo, T., Jaeger, S., Rasmussen, A., RantioLehtimaki, A., Severova, E., Kukkonen, J. A numerical model of birch pollen emission and dispersion in the atmosphere. Description of the emission module. Int. J. Biometeorol., in press.

Sunyer, J., Jarvis, D., Pekkanen, J., Chinn, S., Janson, C., Leynaert, B., et al., 2004. Geographic variations in the effect of atopy on asthma in the European Community Respiratory Health Study. J. Allergy Clin. Immunol. 114 (5), 1033-1039.

van Ree, R., Chapman, M.D., Ferreira, F., Vieths, S., Bryan, D., Cromwell, O., et al., 2008. The CREATE project: development of certified reference materials for allergenic products and validation of methods for their quantification. Allergy 63 (3), 310-326.

Vogel, L., Luttkopf, D., Hatahet, L., Haustein, D., Vieths, S., 2005. Development of a functional in vitro assay as a novel tool for the standardization of allergen extracts in the human system. Allergy 60 (8), 1021-1028.

Ziska, L.H., Beggs, P.J., 2012. Anthropogenic climate change and allergen exposure: the role of plant biology. J. Allergy Clin. Immunol. 129 (1), 27-32. 